US Army Corps

of Engineers $S_{\circledast}$

Engineer Research and

Development Center

Great Lakes Restoration Initiative

\title{
Aligning Research and Monitoring Priorities for Benthic Cyanobacteria and Cyanotoxins: A Workshop Summary
}

Kaytee Pokrzywinski, Kaitlin Volk, Taylor Rycroft, Susie Wood,

Tim Davis, and Jim Lazorchak

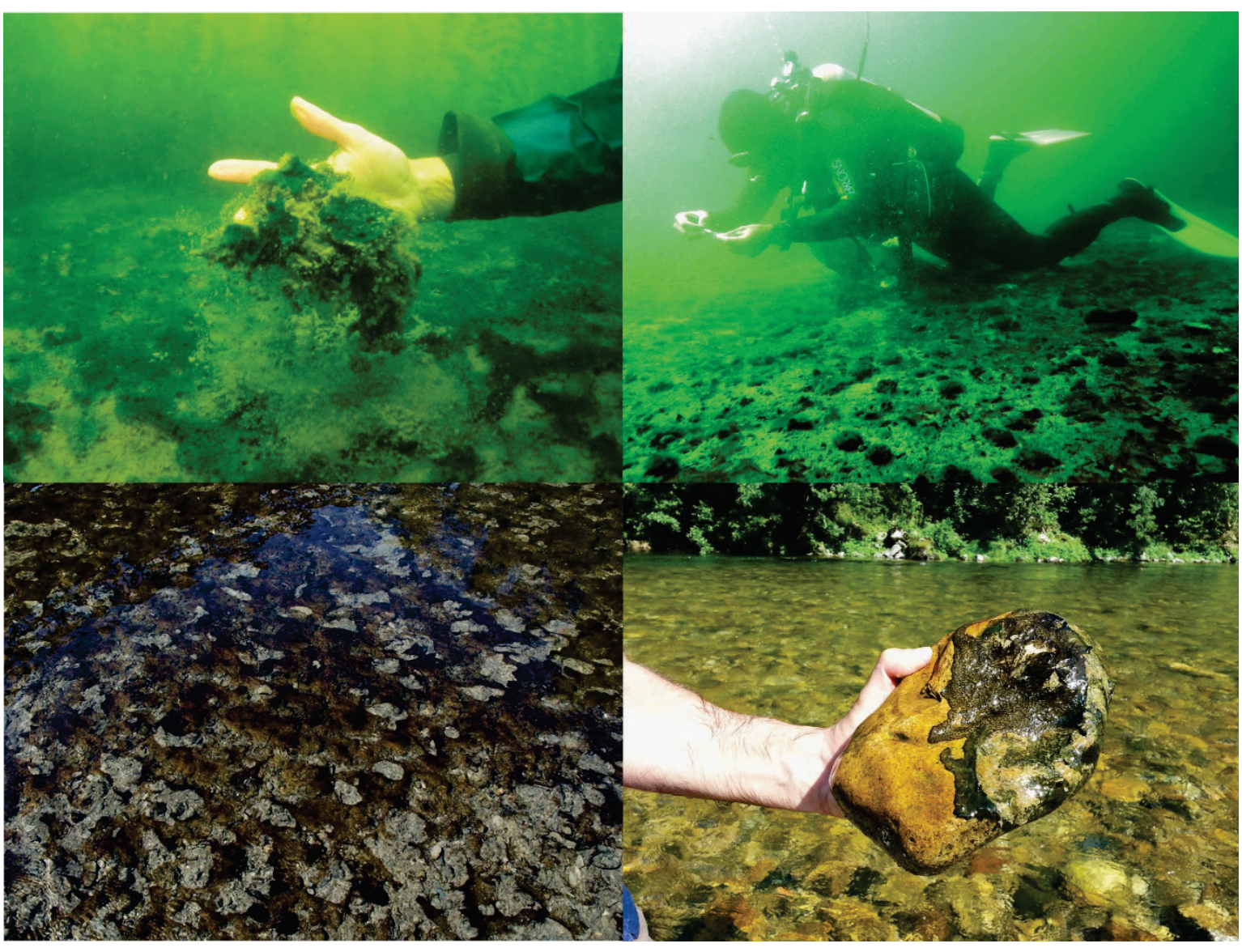


The U.S. Army Engineer Research and Development Center (ERDC) solves the nation's toughest engineering and environmental challenges. ERDC develops innovative solutions in civil and military engineering, geospatial sciences, water resources, and environmental sciences for the Army, the Department of Defense, civilian agencies, and our nation's public good. Find out more at www.erdc.usace.army.mil.

To search for other technical reports published by ERDC, visit the ERDC online library at https://erdclibrary.on.worldcat.org/v2. 


\section{Aligning Research and Monitoring Priorities for Benthic Cyanobacteria and Cyanotoxins: A Workshop Summary}

Kaytee Pokrzywinski and Taylor Rycroft

Environmental Laboratory

US Army Engineer Research and Development Center

3909 Halls Ferry Road

Vicksburg, MS 39180

Kaitlin Volk

Credere Associates, LLC.

776 Main Street

Westbrook, Maine 04092

Susie Wood

Cawthron Institute

98 Halifax Street East

Nelson 7010, New Zealand

\author{
Tim Davis \\ Department of Biological Sciences \\ Bowling Green State University \\ Bowling Green, Ohio 43403 \\ Jim Lazorchak \\ National Exposure Research Laboratory \\ US Environmental Protection Agency Office of \\ Research and Development \\ Cincinnati, Ohio, USA
}

Final report

Approved for public release; distribution is unlimited.

Prepared for US Army Corps of Engineers, Buffalo District, and the Great Lakes Restoration Initiative

Buffalo, NY 14207-3106

Under MIPR W81EU680856786 


\section{Abstract}

In 2018, the US Army Engineer Research and Development Center partnered with the US Army Corps of Engineers-Buffalo District, the US Environmental Protection Agency, Bowling Green State University, and the Cawthron Institute to host a workshop focused on benthic and sediment-associated cyanobacteria and cyanotoxins, particularly in the context of harmful algal blooms (HAB). Technical sessions on the ecology of benthic cyanobacteria in lakes and rivers; monitoring of cyanobacteria and cyanotoxins; detection of benthic and sediment-bound cyanotoxins; and the fate, transport, and health risks of cyanobacteria and their associated toxins were presented. Research summaries included the buoyancy and dispersal of benthic freshwater cyanobacteria mats, the fate and quantification of cyanotoxins in lake sediments, and spatial and temporal variation of toxins in streams. In addition, summaries of remote sensing methods, omic techniques, and field sampling techniques were presented. Critical research gaps identified from this workshop include (1) ecology of benthic cyanobacteria, (2) identity, fate, transport, and risk of cyanotoxins produced by benthic cyanobacteria, (3) standardized sampling and analysis protocols, and (4) increased technical cooperation between government, academia, industry, nonprofit organizations, and other stakeholders. Conclusions from this workshop can inform monitoring and management efforts for benthic cyanobacteria and their associated toxins.

DISCLAIMER: The contents of this report are not to be used for advertising, publication, or promotional purposes. Citation of trade names does not constitute an official endorsement or approval of the use of such commercial products. All product names and trademarks cited are the property of their respective owners. The findings of this report are not to be construed as an official Department of the Army position unless so designated by other authorized documents. 


\section{Contents}

Abstract............................................................................................................................... if

Figures and Tables.....................................................................................................................................

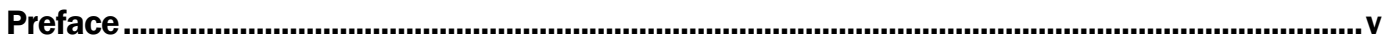

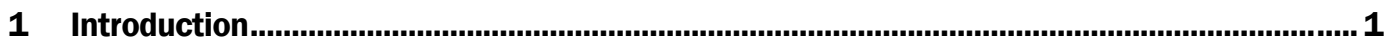

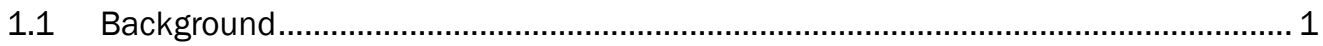

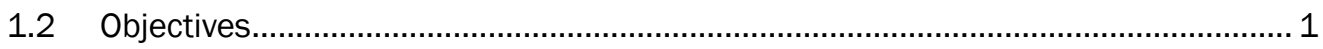

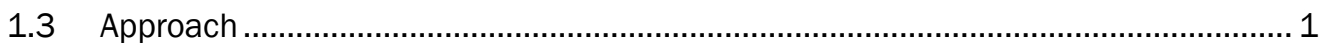

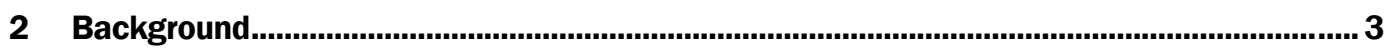

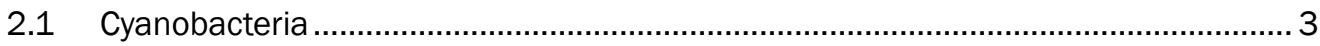

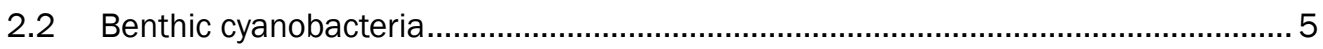

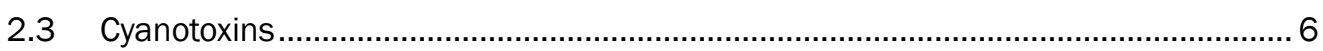

3 Prior and Current Research...................................................................................................10

3.1 Benthic cyanobacterial ecology ............................................................. 10

3.2 Quantitation of cyanotoxins ........................................................................ 11

3.3 Spatiotemporal variations in cyanobacteria and cyanotoxins................................. 12

Conclusions................................................................................................... 13

4 Monitoring and Management Options................................................................................14

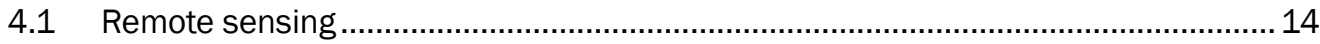

4.2 Field sampling.............................................................................................. 15

4.3 Omics approaches........................................................................................ 15

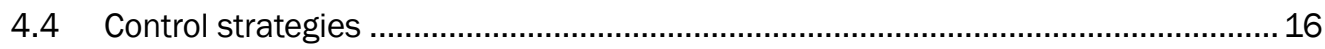

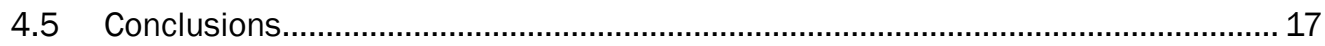

5 Identifying Research and Management Priorities ..........................................................18

5.1 Determine the ecology of benthic cyanobacteria .................................................. 18

5.2 New sampling strategies .............................................................................. 19

5.3 Determine the fate, transport, and toxicity of cyanotoxins ................................... 19

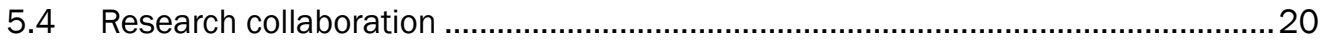

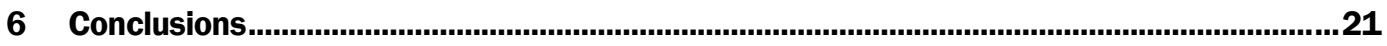

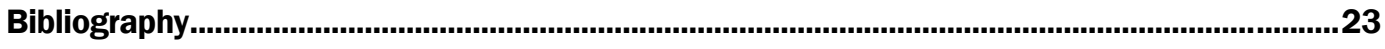

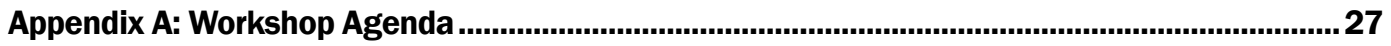

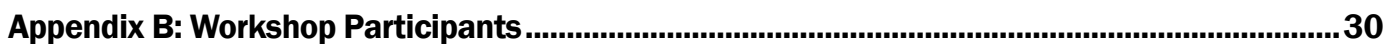

Report Documentation Page 


\section{Figures and Tables}

\section{Figures}

Figure 1. Images of two benthic cyanobacteria. A and C: Anabaena cells (400 $\times$ ) and spires; B and D: Phormidium cells (400×) and mat in the Eel River, California (BoumaGregson, Kudela, and Power 2018, 5).

Figure 2. Concentrations of microcystin $(\mu \mathrm{g} / \mathrm{L})$ in water samples collected from inland lakes during the 2007 US Environmental Protection Agency (USEPA) National Lakes Assessment (modified from Loftin et al. 2016b, 82, accessed from USGS n.d.). Symbols represent the risk of adverse human health effects according to the World Health Organization (WHO)

\section{Tables}

Table 1. Benthic vs. planktonic genera of cyanobacteria and their associated toxins. Modified from Nienaber and Steinitz-Kannan 2018, 36-38, 55-136. Genera with mostly attached species are benthic, while genera with mostly free-floating species are planktonic. Many benthic species can be found in the plankton as they are carried from the littoral zone; these are tychoplanktonic.

Table 2. Cyanotoxin classification, target, and lethal dose. Modified from Nienaber and Steinitz-Kannan 2018, 36-38. LD50 refers to the median lethal dose and is the amount of the toxin required per kilogram of body weight to kill half of the test population.

References: (1) Carmichael 1997; (2) Sivonen et al. 1989; (3) Chen et al. 2013; (4)

Carmichael et al. 1977; (5) Fawell et al. 1999; (6) Skulberg et al. 1992; (7) Lilleheil et al. 1997; (8) Metcalf and Codd 2014; (9) Pearson et al. 2010; (10) Mahmood and Carmichael 1986a; (11) Kuiper-Goodman et al. 1999; (12) Ohtani et al. 1992; (13)

Sivonen and Jones 1999; (14) Weiss et al. 1989. 


\section{Preface}

The information reported herein was funded under MIPR W81EU680856786 and presented in a workshop organized by the US Army Engineer Research and Development Center (ERDC), Environmental Laboratory (EL) in partnership with the US Army Corps of Engineers (USACE) Buffalo District (LRB), the US Environmental Protection Agency (USEPA), Bowling Green State University (BGSU), and the Cawthron Institute. The workshop was funded by the Great Lakes Restoration Initiative (GLRI); the New Zealand Ministry of Business, Innovation, and Employment; the Ohio Sea Grant Program; the Ohio Department of Higher Education; the Lonza Group; the Aquatic Ecosystem Restoration Foundation; and the LRB.

The authors gratefully acknowledge the substantial contributions to the workshop by all of the workshop organizers: Kaytee Pokrzywinski, Brooke Stevens, and Andrew McQueen of ERDC; Susie Wood and Jonathan Puddick of the Cawthron Institute; Timothy Davis of BGSU; and Jim Lazorchak of the USEPA, along with the contributions of invited speakers Keith Bouma-Gregson, Tim Davis, Erich Emery, Richard Harrison, Meredith Howard, Miriam Kannan, Keith Loftin, Jingrang Lu, Andrew McQueen (Chair), Kaytee Pokrzywinski, Jonathan Puddick (Chair), Heather Raymond (Chair), Erin Stelzer, Mark Rowe, Susie Wood (Chair), Jade Young, and Arthur Zastepa. The authors also appreciate the time and dedication of the breakout session leads and note takers in addition to the over 75 participants and technical experts. Reviews of this report were provided by Dr. Karl Indest and Dr. Victor Medina.

This technical note was written by Kaytee Pokrzywinski, Kaitlin Volk, Taylor Rycroft, Susie Wood, Tim Davis, and Jim Lazorchak. For additional information, contact Mr. Taylor Rycroft, Taylor.E.Rycroft@usace.army.mil, or the Acting Program Manager, Aquatic Nuisance Species Research Program, Mr. Michael Greer, Michael.J.Greer@usace.army.mil.

At the time of publication of this report, Mr. Jay Lindsay was Chief, EPR; Mr. Warren Lorentz was Chief, EPED; Dr. Edmond J. Russo was the Director of EL; COL Teresa A. Schlosser was Commander of the ERDC; and Dr. David W. Pittman was the ERDC Director. 


\section{Introduction}

\subsection{Background}

Cyanobacteria, also known as blue-green algae or cyanophyta, is a phylum of photosynthetic bacteria found naturally in fresh, brackish, and marine waters (Nienbar and Steinitz-Kannan 2018). They play many important ecological roles but can also grow at significant rates and form "blooms" under certain environmental conditions (USEPA 2019). Cyanobacterial blooms may adversely affect human and environmental health, including exposure to potent toxins if species of toxic cyanobacteria are present in the bloom (Puddick et al. 2014). Blooms have likely occurred since the initial occurrence of cyanobacteria, but they have become more frequent in recent decades because of human disturbances like eutrophication (USEPA 2019). Previous research on bloom occurrence, management, and consequences have focused largely on free-floating planktonic species. Publications on planktonic cyanobacteria blooms have increased at a greater rate than those on benthic cyanobacteria blooms in the past five years (Wood et al. 2020). Additionally, most of the published work on benthic cyanobacteria focuses on characterizing toxins and the cyanobacteria that produce them and not on their ecology, occurence, or management (Wood et al. 2020). This focus has resulted in research gaps on the life cycle of benthic cyanobacteria, the environmental conditions that promote proliferation and toxin production, the potential for benthicpelagic coupling, and solutions to prevent or manage benthic blooms (Wood et al. 2020).

\subsection{Objectives}

Given the potential for adverse ecological, animal, and human health effects, investigations into cyanobacteria must include benthic species to develop a more holistic understanding of cyanobacterial ecology and toxin production. Scientists, resource managers, industry, and other stakeholders must establish thorough and collaborative research efforts for benthic cyanobacteria.

\subsection{Approach}

To initiate the identification of knowledge gaps and research priorities for benthic cyanobacteria, the US Army Engineer Research and Development 
Center (ERDC) partnered with the US Army Corps of Engineers-Buffalo District, the US Environmental Protection Agency (USEPA), Bowling Green State University (BGSU), and the Cawthron Institute to host the workshop "CyanoSED: A Workshop on Benthic Cyanobacteria and Cyanotoxins" in Cincinnati, Ohio, 6-7 August 2018. The workshop provided a forum for leading water resource managers (agencies and commercial applicators), scientists, regulators, and other interested parties to present and discuss issues surrounding benthic cyanobacteria, harmful algal blooms (HABs), and cyanotoxins in waterbodies across the world. The workshop consisted of approximately 76 representatives from the United States, Canada, and New Zealand, and it included technical sessions focused on current research studies; the ecology of benthic cyanobacteria in lakes and rivers; methods for detecting, monitoring, and tracking cyanobacterial cells and toxins; and the fate, transport, and health and environmental risks of cyanotoxins. Following technical sessions, attendees participated in break-out sessions designed to stimulate discussion on specified topics. The workshop agenda and a list of participants are available in appendices A and B.

The objectives of the workshop were to

1. Understand current research in benthic and sediment-associated HABs related to benthic mat-forming (including attached, periphytic, and filamentous) cyanobacteria and benthic-pelagic (planktonic) coupling of bloom events.

2. Identify knowledge gaps and topic areas worth pursing in further detail.

3. Facilitate engagement among federal, local, and state government agencies; academic institutions; and industry partners to continue coordination and collaboration on benthic and sediment-associated HABs issues.

This report provides a summary of the findings from the workshop. The summary highlights benthic and sediment-associated cyanobacteria and cyanotoxin research and management priorities and suggests resources to help educate managers, stakeholders, and legislators worldwide. 


\section{Background}

\subsection{Cyanobacteria}

Cyanobacteria are a group of photosynthetic microorganisms responsible for the oxygenation of Earth's atmosphere millions of years ago (Dick and Lam 2015). They are commonly referred to as blue-green algae because of their bluish-green color and aquatic lifestyle but are actually bacteria because they lack a nucleus and other high-complexity organelles (Nienbar and Steinitz-Kannan 2018). Because of the increasing occurrence of freshwater bloom events, in which one or multiple cyanobacteria species grow at a rapid rate, dominating the benthos or water column in response to freshwater eutrophication, cyanobacteria have become a source of heightened concern in recent years. The USEPA defines such an event as a bloom when cell densities exceed 20,000 cells $/ \mathrm{mL}^{1}$, a threshold set by the World Health Organization (WHO); these blooms are commonly referred to as cyanobacteria harmful algal blooms (cyanoHABs) (USEPA 2017).

CyanoHABs can negatively impact the aquatic ecosystem by altering its chemical and biotic composition. Adverse impacts include increased turbidity that shades macrophytes or causes physical smothering, production of foul-tasting and -smelling compounds, extensive deoxygenation that can cause anoxic zones and fish kills, and the release of potent cyanotoxins linked to a variety of human health and environmental consequences (Paerl 1988; Puddick et al. 2014). There are upwards of 15 genera of cyanobacteria capable of producing cyanotoxins (Table 1). However, not all species within these genera carry the genes necessary to produce toxins, and many that do carry the genes do not produce toxins at levels detectable by standard laboratory methods outside of bloom conditions (Nienaber and Steinitz-Kannan 2018).

1. For a full list of the spelled-out forms of the units of measure used in this document, please refer to US Government Publishing Office Style Manual, 31st ed. (Washington, DC: US Government Publishing Office, 2016), 248-52, https://www.govinfo.gov/content/pkg/GPO-STYLEMANUAL2016/pdf/GPO-STYLEMANUAL-2016.pdf. 
Table 1. Benthic vs. planktonic genera of cyanobacteria and their associated toxins. Modified from Nienaber and Steinitz-Kannan 2018, 36-38, 55-136. Genera with mostly attached species are benthic, while genera with mostly free-floating species are planktonic. Many benthic species can be found in the plankton as they are carried from the littoral zone; these are tychoplanktonic.

\begin{tabular}{|c|c|c|}
\hline Genera & Primary location & Cyanotoxin \\
\hline Anabaena & Benthic, tychoplanktonic & $\begin{array}{l}\text { Microcystins } \\
\text { Anatoxin-a } \\
\text { Anatoxin-a(S) } \\
\text { Saxitoxin } \\
\text { Cylindrospermopsins }\end{array}$ \\
\hline Anabaenopsis & Planktonic & Microcystins \\
\hline Aphanizomenon & Planktonic & $\begin{array}{l}\text { Nodularins } \\
\text { Anatoxin-a } \\
\text { Saxitoxins } \\
\text { Cylindrospermopsins }\end{array}$ \\
\hline Arthrospira & Benthic (few planktonic) & $\begin{array}{l}\text { Microcystins } \\
\text { Anatoxin-a }\end{array}$ \\
\hline Cylindrospermum & Benthic & Anatoxin-a \\
\hline Cylindrospermopsis & Planktonic & $\begin{array}{l}\text { Saxitoxins } \\
\text { Cylindrospermopsins }\end{array}$ \\
\hline Dolichospermum & Planktonic & $\begin{array}{l}\text { Microcystins } \\
\text { Anatoxin-a } \\
\text { Anatoxin-a(S) } \\
\text { Saxitoxins } \\
\text { Cylindrospermopsins }\end{array}$ \\
\hline Gloeotrichia & $\begin{array}{l}\text { Benthic, tychoplanktonic (two } \\
\text { planktonic spp.) }\end{array}$ & Microcystins \\
\hline Hapalosiphon & Benthic & Microcystins \\
\hline Lyngbya & Benthic, tychoplanktonic & $\begin{array}{l}\text { Saxitoxins } \\
\text { Aplysiatoxin } \\
\text { Lyngbyatoxin-a }\end{array}$ \\
\hline Microcystis & Planktonic, tychoplanktonic & $\begin{array}{l}\text { Microcystins } \\
\text { Anatoxin-a }\end{array}$ \\
\hline Nostoc & Benthic & $\begin{array}{l}\text { Microcystins } \\
\text { Nodularins }\end{array}$ \\
\hline Nodularia & Benthic, planktonic & Nodularins \\
\hline Oscillatoria & Benthic, tychoplanktonic & $\begin{array}{l}\text { Microcystins } \\
\text { Anatoxin-a } \\
\text { Aplysiatoxin } \\
\text { Lyngbyatoxin-a }\end{array}$ \\
\hline Phormidium & Benthic & $\begin{array}{l}\text { Microcystins } \\
\text { Anatoxin-a }\end{array}$ \\
\hline Planktothrix & Planktonic (few benthic) & $\begin{array}{l}\text { Microcystins } \\
\text { Anatoxin-a } \\
\text { Saxitoxins }\end{array}$ \\
\hline
\end{tabular}




\begin{tabular}{|l|l|l|}
\hline Genera & Primary location & Cyanotoxin \\
\hline & & $\begin{array}{l}\text { Aplysiatoxin } \\
\text { Lyngbyatoxin-a }\end{array}$ \\
\hline Plectonema & Benthic & Microcystins \\
\hline Raphidiopsis & Planktonic & $\begin{array}{l}\text { Anatoxin-a } \\
\text { Cylindrospermopsins }\end{array}$ \\
\hline Rivularia & Benthic & Microcystins \\
\hline
\end{tabular}

\subsection{Benthic cyanobacteria}

Cyanobacteria species can be broadly categorized as benthic or planktonic (Table 1, Figure 1). For the purposes of the workshop and this report, the term benthic cyanobacteria includes cyanobacteria in, on, or near sediment or other bottom substrate (part of the benthos), while planktonic cyanobacteria are generally considered to be free floating in the water column (part of the pelagic zone). Benthic mats and films of cyanobacteria and other microorganisms are also known as periphyton when attached to submerged substrate or epiphyton when attached to plants. Distinguishing between benthic and planktonic species can be challenging, as primarily benthic species may be found in the water column during resuspension from substrate disturbance or during certain life stages, and primarilyplanktonic species may settle to the bottom, become trapped in mats, or overwinter in the sediment. Blooms of planktonic species in lakes and estuaries have received significant research attention pertaining to their cause, detection methods, impacts, and management strategies (NOAA 2019; ORSANCO 2019; USEPA 2019). Benthic species, however, are comparatively less studied despite their capacity to form sizable blooms that can negatively impact human, animal, and ecosystem health through the production of toxins, reduction in water quality, and physical mat formation (Quiblier et al. 2013). In addition to the affects of toxins on the local community, described in the next section, the physical formation of benthic biofilms and mats alters macroinvertebrate species assemblage and diversity and smothers sessile organisms like freshwater bivalves (Quiblier et al. 2013). 
Figure 1. Images of two benthic cyanobacteria. A and C: Anabaena cells (400×) and spires; B and D: Phormidium cells (400×) and mat in the Eel River, California (Bouma-Gregson, Kudela, and Power 2018, 5).

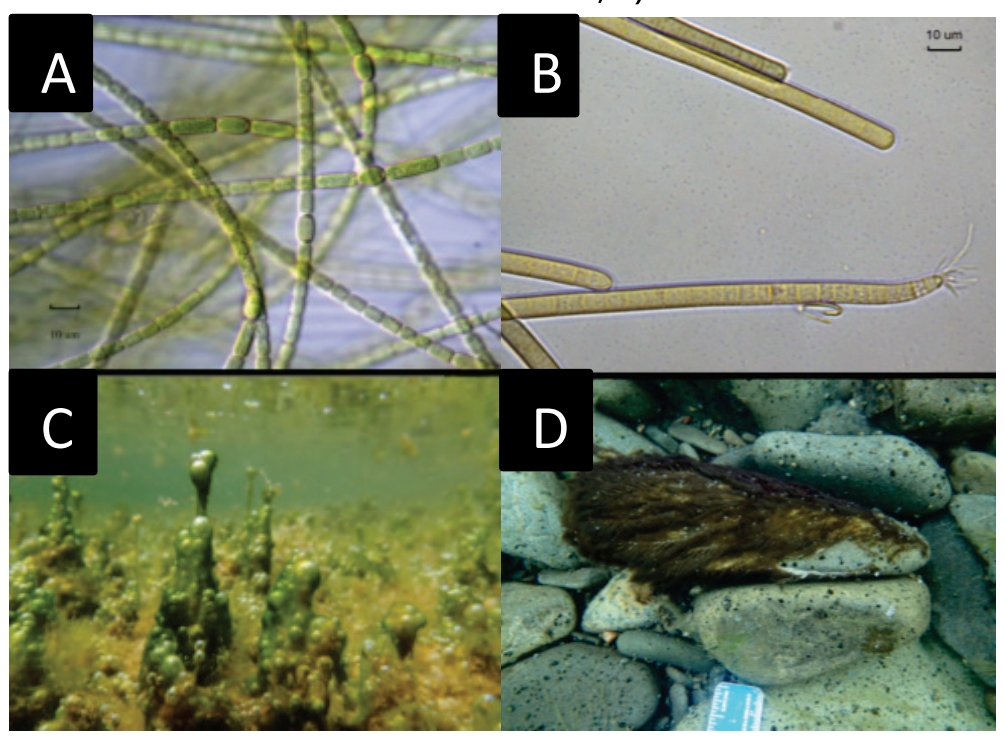

Current understanding of the lifecycle of benthic cyanobacteria consists of three steps: (1) establishment under favorable environmental conditions, (2) formation and growth of mats over submerged sediments, and (3) detachment of mats and subsequent drift (Newcombe et al. 2010). Mats are more likely to detach from the substrate if fine sediment accumulates underneath the mat, bubbles accumulate within the mat, or fast-moving water scours the mat (McAllister, Wood, and Hawes 2016). Detached mats can then float downstream and accumulate in areas of slower-moving water (Bouma-Gregson, Kudela, and Power 2018). Toxins and other metabolites, such as the foul-smelling and -tasting compounds geosmin and 2-methylisoborneol (MIB), may disperse more freely from floating mats (Newcombe et al. 2010). The ecology of benthic cyanobacteria species requires considerable research into the environmental conditions that promote bloom events and toxin production; benthic cyanotoxin fate and transport; and best practices for sampling, monitoring, and managing benthic cyanobacterial mats. Only through the detailed understanding of all life stages of benthic cyanobacteria will researchers and water resourse managers be able to accurately predict and subsequently manage benthic cyanobacteria blooms (Hense and Beckmann 2006).

\subsection{Cyanotoxins}

A number of classes of toxins is known to be produced by both pelagic and benthic cyanobacteria, including microcystins, anatoxins, nodularins, 
cylindrospermopsin, lyngbyatoxins, and saxitoxins (Sivonen and Jones 1999). These toxins can be grouped into three broad categories according to chemical structure: cyclic peptides, alkaloids, and lipopolysaccharides (LPS) (Table 2). Many are acutely toxic to humans and have been shown to cause damage to the skin, liver, gastrointestinal tract, and nerve synapses and axons and (Sivonen and Jones 1999). Chronic exposure can lead to tumors, cancer, neurodegeneration, and a loss in reproductive function (Sivonen and Jones 1999; Backer 2012).

Table 2. Cyanotoxin classification, target, and lethal dose. Modified from Nienaber and Steinitz-Kannan 2018, 36-38. LD50 refers to the median lethal dose and is the amount of the toxin required per kilogram of body weight to kill half of the test population. References:

(1) Carmichael 1997; (2) Sivonen et al. 1989; (3) Chen et al. 2013; (4) Carmichael et al. 1977; (5) Fawell et al. 1999; (6) Skulberg et al. 1992; (7) Lilleheil et al. 1997; (8) Metcalf and

Codd 2014; (9) Pearson et al. 2010; (10) Mahmood and Carmichael 1986a; (11) Kuiper-

Goodman et al. 1999; (12) Ohtani et al. 1992; (13) Sivonen and Jones 1999; (14) Weiss et al. 1989.

\begin{tabular}{|c|c|c|c|c|}
\hline Toxin class & Subclass & Cyanotoxin & Target & $\begin{array}{l}\mathrm{LD}_{50} \\
\mathrm{mg} / \mathrm{kg}\end{array}$ \\
\hline \multirow{2}{*}{$\begin{array}{l}\text { Cyclic } \\
\text { peptides }\end{array}$} & \multirow[t]{2}{*}{ None } & Microcystins & Liver [1] & $0.02-0.15[1]$ \\
\hline & & Nodularins & Liver [2] & $0.06[3]$ \\
\hline \multirow[t]{4}{*}{ Alkaloids } & \multirow{2}{*}{$\begin{array}{l}\text { Neurotoxic } \\
\text { alkaloids } 1 \\
\text { (anatoxins) }\end{array}$} & $\begin{array}{l}\text { Anatoxin-a and } \\
\text { Homoanatoxin-a }\end{array}$ & $\begin{array}{l}\text { Neuro-muscular junction } \\
\text { (NMJ) [4] NMJ [6] }\end{array}$ & $\begin{array}{l}0.375[5] \text { and } \\
0.29-0.58[7]\end{array}$ \\
\hline & & Anatoxin-a(S) & NMJ [8] & 0.02 [10] \\
\hline & $\begin{array}{l}\text { Neurotoxic } \\
\text { alkaloids } 2 \\
\text { (saxitoxins) }\end{array}$ & Saxitoxins & Nerve [8] & $0.01[9]$ \\
\hline & $\begin{array}{l}\text { Cytotoxic } \\
\text { alkaloids }\end{array}$ & Cylindrospermopsins & $\begin{array}{l}\text { Cells, liver and kidneys } \\
\text { [11] }\end{array}$ & $0.30[12]$ \\
\hline LPS & None & LPS & Skin [13] & $?$ \\
\hline Amino acid & None & BMAA & Nerve [14] & $?$ \\
\hline \multirow[t]{2}{*}{ Various } & \multirow[t]{2}{*}{ None } & Aplysiatoxin & Skin $[8,13]$ & $?$ \\
\hline & & Lyngbyatoxin-a & Skin $[8,13]$ & $?$ \\
\hline
\end{tabular}

Microcystin derivatives have gained the most attention because they are the most prolific of sampled cyanotoxins (Figure 2) and have a proven negative impact on human health (Fletcher et al. 2015). Acute exposure to high doses of microcystins can cause liver hemorrhage or liver failure in mammals, including humans, leading to death. Chronic exposure to small doses, such as those potentially found in drinking water sources, may lead to tumor growth, primarily on the liver but also in other organs (KuiperGoodman, Falconer, and Fitzgerald 1999). Microcystins have been found in organisms at multiple trophic levels, including zooplankton, 
macroinvertebrates, mussels, crayfish, fish, and even bats, deer, and sea otters, demonstrating their ability to bioaccumulate (Sivonen and Jones 1999; Miller et al. 2010).

Figure 2. Concentrations of microcystin $(\mu \mathrm{g} / \mathrm{L})$ in water samples collected from inland lakes during the 2007 US Environmental Protection Agency (USEPA) National Lakes Assessment (modified from Loftin et al. 2016b, 82, accessed from USGS n.d.). Symbols represent the risk of adverse human health effects according to the World Health Organization (WHO).

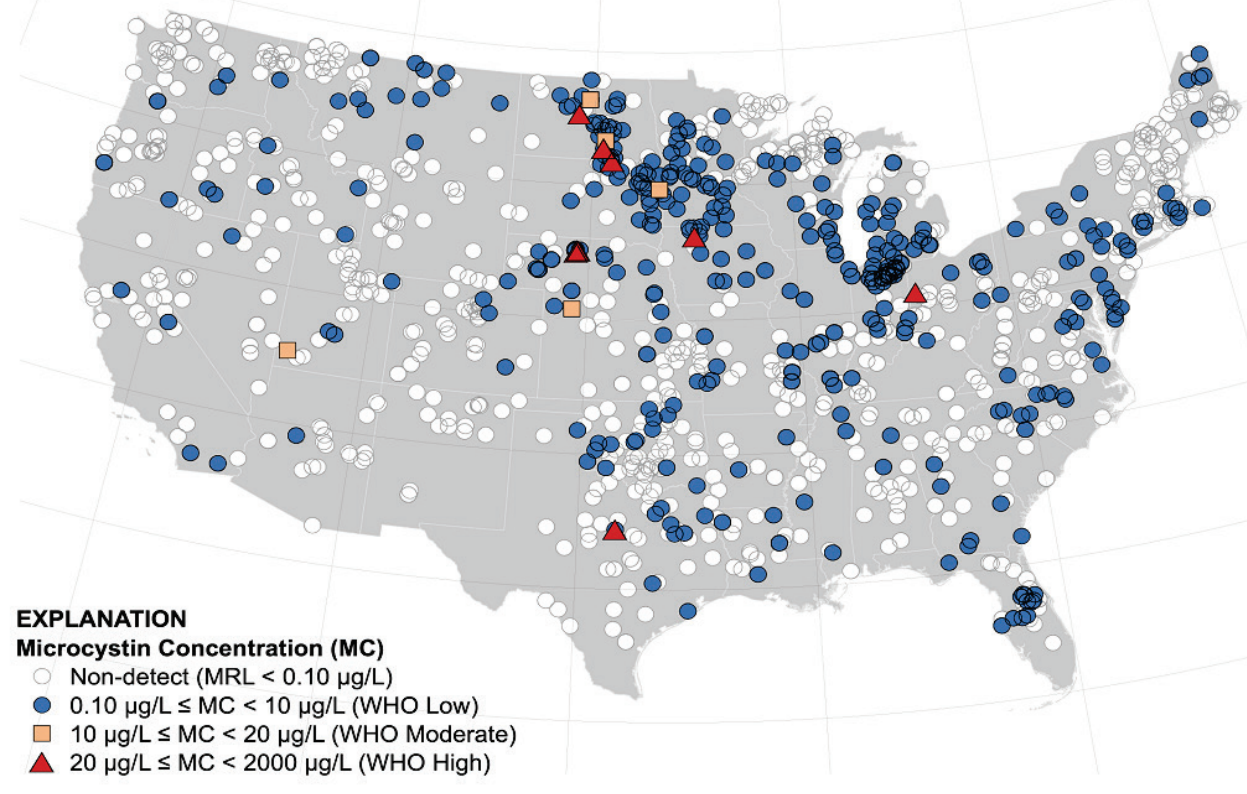

The primary pathway of exposure to cyanotoxins for most organisms is the ingestion of cyanobacteria cells, water, or other organisms already containing the toxins through bioaccumulation. Cyanotoxins can cause skin irritation upon dermal contact (Backer 2012) and can also be aerosolized, making inhalation a possible, but understudied, exposure route (Backer et al. 2010). Cyanotoxins have mixed effects on the organisms they come in contact with. Studies on zooplankton have showed inconsistent results (Sivonen and Jones 1999; Ferrao-Filho and Kozlowsky-Suzuki 2011; Princiotta, Hendricks, and White 2019). Carbis et al. (1997) found that microcystin damaged the liver, gills, and epithelium of European carp. Several strains of bacteria are able to degrade high levels of specific cyanotoxins, suggesting they may use these substrates for growth and may have a facultative symbiotic relationship with toxinproducing strains (Sivonen and Jones 1999). Previous research has also found that some benthic-grazing zooplankton and fish, like tilapia and silver carp, graze selectively on nontoxic benthic mats, possibly driving an increase in the occurrence of toxic cyanobacteria over time (DeMott, 
Zhang, and Carmichael 1991). Overall, the identification and distribution of less-studied and unidentified cyanotoxins, the effects of cyanotoxins on the ecology of aquatic and littoral ecosystems, and the cumulative effects of exposure to multiple different cyanotoxins requires more research. 


\section{Prior and Current Research}

Toxic cyanobacteria blooms have become an increasing problem across the globe, yet applied research has generally focused on planktonic blooms and ignored the occurence of benthic blooms, as well as the influence of benthic cyanobacteria communities on planktonic cyanoHAB events. Much of the effort on benthic cyanobacteria has focused on detecting and tracking the presence of different cyanotoxins (Zastepa et al. 2015; Fletcher et al. 2015). Other studies have examined the role of environmental factors (that is, temperature, light, flow, nutrients) in toxin production (Zastepa et al. 2017b; Loftin et al. 2016a; D'Agostino et al. 2016), species and toxin identification and documentation (Nienaber and Steinitz-Kannan 2018; Puddick et al. 2014; Quiblier et al. 2013), and downstream effects of cyanotoxins and bioaccumulation (Miller et al. 2010; Bouma-Gregson, Kudela, and Power 2018).

Research efforts presented at the workshop included the extraction and analysis of cyanotoxins, the distribution and occurrence of toxic cyanobacteria, the influence of environmental conditions and human activity on blooms, the ecology of planktonic species, the dispersal of mats, and the fate and transport of toxins. Three research efforts presented at the workshop are summarized below and are representative of the breadth of research activities discussed at the workshop.

\subsection{Benthic cyanobacterial ecology}

Tipping towards toxicity: benthic freshwater cyanobacteria in California rivers (Bouma-Gregson, Power, and Bormans 2017; Bouma-gregons, Kudela, and Power 2018)-Keith Bouma-Gregson, University of California-Berkeley

In an effort to bring the knowledge on the ecology of benthic cyanobacteria in rivers to a level similar to that of planktonic cyanobacteria, researchers in California are studying the buoyancy and subsequent dispersal capability of mats of Anabaena spp. in the Eel River. Anabaena spp. are epiphytic on filamentous green algae and form a distinctive "spire." They are easily sloughed from the benthic substrate and are, therefore, found mostly in slow-flowing water $(<10 \mathrm{~cm} / \mathrm{s})$. Mats harvested from the river were placed in settling columns in situ under natural ambient light and low-light conditions so that floating ability could be measured as a 
function of light intensity. Floating was found to be caused by the production of oxygen bubbles through photosynthesis in the mat. Under natural light conditions, mats could remain floating for at least four days (the temporal extent of the experiment) but began to sink in less than a day if subjected to low-light conditions. One mat that sunk overnight refloated the next day after photosynthesis recommenced, and clumps from mats used to assess the velocity of floating and sinking began floating within minutes of being exposed to natural light conditions. Clumps with a high proportion of Cladophora spp., a filamentous green algae, took longer to float to the surface than clumps dominated by Anabaena, suggesting that mat buoyancy and dispersal capability dependent on the species composition of the mat. The ability of Anabaena mats to remain buoyant for multiple days will greatly increase their downstream dispersal capacity. This inherent capacity to disperse and accumulate along shorelines is a potential human and animal health risk, as anatoxin-a and microcystins were both identified in samples of floating Anabaena mats collected along the Eel River.

\subsection{Quantitation of cyanotoxins}

Fate and quantitation of cyanotoxins (Microcystin variants) in lake sediments (Zastepa et al. 2015)-Arthur Zastepa, Environment and Climate Change Canada, University of Ottawa

Environment and Climate Change Canada is looking at the distribution, flux, and long-term historical record of microcystins in lake sediments. The research team developed a new analytical method that uses accelerated solvent extraction, hydrophilic-lipophilic balance solid-phase extraction, and reversed-phase high-performance liquid chromatographytandem mass spectrometry (HPLC-MS) to extract and quantify microcystins from sediments. Using this method, microcystins were identified in five of the seven lakes sampled. Microcystins were found throughout the $46 \mathrm{~cm}$ sediment core in some lakes, such as Lake Baptiste in Alberta, which represents approximately 200 years of historical data. This analysis shows that microcystins, and likely other cyanotoxins, are not a new occurrence and are persistent through space and time. However, increased eutrophication of lakes was significantly correlated with an increase in total microcystin concentrations, corroborating the role human disturbance has played in increasing cyanoHAB events. Sediment cores can also be used to determine the natural baseline for microcystin concentrations in a given waterbody. There was no correlation between 
climate and toxin concentration on an annual scale, but a monthly scale did show highest concentrations when surface waters were warmest. Passive diffusion from the sediment to the water column was found to be a source of microcystins in addition to direct production by living cells. The rate of diffusion depended on the microcystin congener and sediment type and may represent an ongoing exposure risk scenario even in the absence of visible blooms or mats.

\subsection{Spatiotemporal variations in cyanobacteria and cyanotoxins}

Spatial and temporal variation in microcystin occurrence in wadeable streams in the southeastern United States (Loftin et al. 2016a)-Keith Loftin, US Geological Survey (USGS)

On a five-year rotation, the USEPA conducts the National Lake Assessment, National Wetlands Assessment, National Rivers and Streams Assessment, and National Coastal Assessment to gain a general understanding of the state and health of the nation's waterways. The USGS also contributed to long-term monitoring efforts by completing a series of stream quality assessments for five regions of the United States from 2013 to 2017. These collaborative assessments, along with other regional assessments, all included cyanobacteria and cyanotoxins in their sampling methodology. Historical work by the USGS in Southeastern wadeable streams (Alabama, Georgia, North Carolina, and South Carolina) from 1993 to 2011 found that samples of periphyton were dominated by diatoms and cyanobacteria, with mean relative biovolumes of $18 \%$ and $7.8 \%$, respectively. Nearly $75 \%$ of all samples contained genera of benthic cyanobacteria with the potential to produce microcystin. Additionally, filamentous forms of potential microcystin producers accounted for $68 \%$ of the cyanobacteria community on average and represented 22 different toxin-capable genera. Benthic cyanobacteria capable of producing anatoxins, cylindrospermopsins, and saxitoxins were also observed in the study. A repeat of the study in 2014 found microcystins in 39\% of the 75 streams sampled, with a maximum concentration below the level of concern set by the WHO. Six sites of different land-use types and microcystin concentrations were sampled monthly from June to October to study temporal variation of toxin concentrations. Maximum discharge, maximum total nitrogen: total phosphorus (TN:TP), and minimum water temperature were found to be weakly correlated with microcystin concentration. 


\subsection{Conclusions}

Bouma-Gregson presented an initial study into the ecology of benthic cyanobacteria and their potential to disperse and accumulate in downstream systems (Bouma-Gregson, Power, and Bormans 2017). Zastepa and Loftin presented their research on the correlations they found between human disturbance and HAB events (Zastepa, Pick, and Blais 2017a; Loftin et al. 2016a). Zastepa's group found a correlation with nutrient loading, and Loftin's group found a weak correlation with discharge, surface temperature, and TN:TP. Zastepa and Loftin's groups also demonstrated that cyanotoxins are present at low levels in most waterbodies but can rise to levels considered dangerous to humans and other biota during bloom events, and Bouma-Gregson's group demonstrated that the accumulation of mats along riverbanks is possible and hazardous even in the absence of blooms.

The majority of presentations at the workshop emphasized that current research efforts on benthic cyanobacteria and their associated cyanotoxins are in their nascent stages. Many more studies are needed before our understanding of benthic cyanobacteria and ability to monitor them is comparable to that of planktonic cyanobacteria. Given the mounting evidence of the negative impacts of benthic blooms on water quality and aquatic and terrestrial organisms, and the identification of knowledge gaps, investigations into the ecology, monitoring, and management of benthic cyanobacteria must continue. 


\section{Monitoring and Management Options}

Several strategies to monitor benthic cyanobacteria and their associated toxins have been employed in the field and in the laboratory. However, strategies vary widely between groups, leading to a need for the standardization of monitoring techniques moving forward so that benthic communities and toxins can be properly assessed and compared. A review of several monitoring techniques presented at the workshop, including remote sensing, omics strategies, and field sampling, is described below. Additionally, discussions at the workshop revealed that a lack of viable control options for benthic cyanobacteria blooms currently exists; the proposed management techniques are described below.

\subsection{Remote sensing}

Remote sensing can be conducted with a variety of technologies, including satellites, planes, or drones equipped to gather multispectral, hyperspectral, or more basic image data. The National Oceanic and Atmospheric Administration (NOAA) has used a Medium Resolution Imaging Spectrometer (MERIS) satellite to identify planktonic blooms of cyanobacteria by tracking levels of surface chlorophyll $a$ (Chl-a) in Lake Erie (Wynne et al. 2010). Using modeled currents and other data, researchers can now forecast where planktonic blooms will be in the near future, allowing local citizens and businesses to plan accordingly and avoid dangerous areas (Wynne et al. 2010; Rowe et al. 2016). However, current remote-sensing technology cannot penetrate deeply enough into water to image the substrate of lakes or streams, making it inefficient for sensing benthic cyanobacteria blooms beyond the occurance of floating mats. Recent research has attempted to link toxin concentrations, which remote sensing cannot detected, to pigments detectable in planktonic blooms, such as Chl-a or phycocyanin (Stumpf et al. 2016). Currently, the mathematical relationship between toxin and surrogate pigment is based on samples collected in the field and is only accurate for a few weeks because of variability in toxin production. This short-term accuracy means that consistent field sampling is still required. Much more research is required before remote sensing for cyanotoxins can be conducted without ground calibration, and even more is required for remotely monitoring benthic cyanobacteria blooms. 


\subsection{Field sampling}

Sampling methods for benthic cyanobacteria will likely need to be depthand substrate-specific. Benthic mats are spatially heterogeneous, so providing a comprehensive picture may require multiple samples from a given location. The number and spatial distribution of samples required for a thorough representation still needs assessment, but past efforts have taken samples randomly or along a transect. Additionally, because sampling will inherently require disturbing the benthos, replicate samples cannot be taken. Multiple devices can obtain samples from softer substrate such as clay, sand, or mud. The Eckman grab, or any variation on a weighted rigid plastic corer, is common. For harder substrate, such as rocks, boulders, or dam walls, cyanobacteria need to be scraped off. Quantitative assessments of benthic cyanobacteria growth have also used removable artificial substrates of known surface area placed at specified locations and depths, which are then recovered and analyzed every one to two months (Newcombe et al. 2010).

Solid-phase adsorption toxin tracking (SPATT) devices are used to sample toxins through passive adsorption of targeted toxins from the water column and onto a resin. SPATTs are a cost-effective tool for detecting toxins and are usually better than grab samples because of the spatial heterogeneity of toxin production and presence. Since SPATT devices require toxins that will adsorb to them from the water column, they are less effective at monitoring for toxins present inside of benthic mats.

\subsection{Omics approaches}

Omics methods analyze genomes, transcriptomes, and proteomes to understand the physiological potential and general ecology and status of phytoplankton communities. Genomics approaches analyze DNA to obtain the identity and biological potential of an organism or community, transcriptomics approaches analyze mRNA to detect which genes are actively being expressed, and proteomics approaches analyze proteins or peptides (Dick and Lam 2015). Using these three processes, researchers can identify cyanobacteria capable of producing toxins, determine whether they are actively producing toxins, and determine presence and quantity of specific toxins in a sample. In addition to identifying new toxin molecules, novel biosynthetic pathways and the physiological regulation and drivers of various metabolic processes can also be determined. However, omics techniques require de novo sequence assembly or a reference database of 
genomic and proteomic information for comparison, or both, and such databases do not exist for most benthic cyanobacteria. However, genome and proteome sequences for pelagic cyanobacteria could be used to guide de novo assembly of novel benthic cyanobacteria.

\subsection{Control strategies}

Chemical treatments are increasingly employed for planktonic algal blooms and are often successful in quickly reducing the bloom. Algaecides directly kill all present algae and cyanobacteria cells, but they may also inadvertently increase toxin concentration upon cell lysis (Touchette, Edwards, and Alexander 2008; Bishop, Johnson, and Rodgers 2019) or cause negative environmental impacts through the increase in heterotrophic bacteria that consume lysed algal biomass or the harsh chemical algaecides deployed (that is, copper-based products). Aluminum sulfate is a fairly common nutrient abatement strategy that works by binding with dissolved inorganic phosphorous, thereby rendering an essential macronutrient required for cyanobacterial growth inaccessible for metabolism. Both of these treatments, however, appear to be insufficient for controlling or limiting benthic cyanobacterial productivity, as the chemicals cannot penetrate deep into the biofilm of the benthic mats and cyanobacteria are known to store nutrients for metabolic processes.

For systems where the flow can be controlled, such as in a stream or river with an upstream dam, scouring has been suggested as a possible way to control mat formation. Mats of cyanobacteria can be sensitive to physical scouring, so the occasional release of water to create flows fast enough to scour the bottom substrate could prevent the formation of large mats or remove mats after formation. The consequences of this scouring to the larger benthic community and to communities downstream of the original mats still requires assessment.

Inoculating a system with nontoxic species of cyanobacteria capable of outcompeting toxic species or augmenting and stimulating native species of macroinvertebrates and fish that graze on benthic mats were discussed by workshop participants as potential biological control strategies. There is some evidence of increased herbivory by two fish species in a coral reef system following a shift toward a cyanobacteria-algal community, suggesting novel and opportunistic feeding that could help control cyanobacteria mats (Ford et al. 2018). However, such behavior has not been documented in a freshwater system. Further complicating the issue, 
some freshwater fish and mussel species have been found to selectively graze only on nontoxic cyanobacteria (DeMott, Zhang, and Carmichael 1991), potentially increasing the prevalence of toxic benthic and planktonic cyanobacteria species.

\subsection{Conclusions}

A number of techniques to detect and monitor cyanobacteria and cyanotoxins are currently being deployed or are under development. However, many techniques under development are based on planktonic monitoring methods, and the complexities and differences associated with converting methods to use for benthic communities still need to be highlighted and resolved. The use of omic techniques on samples of benthic cyanobacteria is a promising avenue, since researchers can ascertain the identity of the present cyanobacteria species, whether the species are capable of producing toxins, the identity of the toxins, and whether the toxins are being actively produced. However, this methodology is often time and cost intensive and therefore not realistic for routine monitoring efforts. Additionally, widespread adoption and use of omic techniques will require researchers to develop and follow a standard methodology for sampling benthic mats and performing analyses. Furthermore, the development of omics approaches can be used to validate emerging techniques for monitoring and detection. Currently, direct management options for benthic cyanobacteria, whether chemical, physical, or biological, are limited and require an increased understanding of the growth and physiology of these benthic proliferations. 


\section{Identifying Research and Management Priorities}

During the workshop, small-group break-out sessions discussed a path forward for improving upon the current state of knowledge in the following focal areas: (1) the ecological understanding of benthic and sediment-associated cyanobacteria, (2) sampling and monitoring strategies for benthic cyanobacteria populations, and (3) the toxicity of cyanotoxins produced by benthic cyanobacteria. Small groups consisted of researchers, regulators, and practitioners with diverse experiences and perspectives. Each group focused on the topic under discussion and applied real-world perspectives to the challenge questions, which ranged in scope and complexity and applied to both scientific and social contexts. The break-out sessions sought to determine whether common themes would emerge during the discussions. Interesting commonalities and important differences emerged owing to the unique perspective of the individuals in each group. Observations and priority follow-on questions from each breakout session are highlighted below.

\subsection{Determine the ecology of benthic cyanobacteria}

- Cyanobacteria are often studied only during bloom events.

- What is the full life-cycle ecology of different cyanobacteria species, and how do stages interplay to produce blooms and toxins?

- How are nutrients and other metabolites cycled internally in mats?

- Under what conditions are benthic cyanobacteria most likely to produce toxins and blooms?

- Which species produce which toxins?

- Which toxins are we missing, and how do we begin to detect them?

- Are blooms composed of one dominant species or multiple species, and does composition change as the bloom progresses?

- What is the effect of invasive species (that is, zebra mussels) on toxic and nontoxic benthic and planktonic cyanobacteria species? 


\subsection{New sampling strategies}

- A standard method or suite of tools for monitoring or tracking benthic cyanobacteria needs to be developed.

- Can planktonic sampling methods be adapted for benthic sampling?

- What is the optimum sampling strategy for different substrate types, mat morphology, and water depth?

- How useful are remote-sensing or long-term in situ water-quality sensors for monitoring benthic cyanobacteria growth and toxin production?

- Can rapid-screening field tests be created for toxic benthic mats?

- A database of benthic cyanobacteria species and their associated toxins needs to be compiled before the potential of omic techniques can be fully realized.

- Can legacy cataloged samples assist in the development of a database?

- Can pelagic sequences assist in de novo sequence assembly for benthic cyanobacteria?

- With what method and under what conditions should different toxins be extracted and stored?

- What are the extraction efficiencies, interferences, and matrix effects of different methods for extracting toxins?

\subsection{Determine the fate, transport, and toxicity of cyanotoxins}

- What are the exposure pathways for aquatic and terrestrial plants and animals?

- Can cyanotoxins be aerosolized or leach into ground water, and what is the associated health risk associated if so?

- What is the risk posed by floating mats accumulated on the shoreline? Can dog deaths be linked to this?

- There is evidence that different toxins bioaccumulate or desorb from the sediment over time, but at what rate and under what conditions? If so, what are the impacts to terrestrial plants, particularly agricultural crops?

- What are the consequences of exposure to multiple toxins for human, wildlife, and ecological health? 
- Lesser-known variants of toxins and novel toxins require further study; they have been understudied because of an emphasis on the established toxins with the most significant human health impacts.

\subsection{Research collaboration}

- The field would greatly benefit from more collaboration between stakeholders.

- The sharing of techniques and tools between research groups would help standardize methods and build important databases and partnerships.

- Improved collaboration between researchers studying the ecology and occurrence of cyanobacteria and researchers studying the hazard and exposure potential from HABs would enable more reliable characterizations of the potential human and environmental health risks posed by benthic cyanobacteria.

- Human health studies should be combined with ecotoxicology studies to set toxin thresholds and health advisory levels that are beneficial to both human and ecological health. 


\section{Conclusions}

The following conclusions were drawn from key points identified by workshop participants. These conclusions will help prioritize and focus future collaborative efforts to significantly improve monitoring and management of toxic benthic cyanobacteria.

- The current understanding of the ecology and monitoring techniques of benthic cyanobacteria and cyanotoxins was reviewed and discussed.

- Much of the life-cycle ecology of benthic cyanobacteria communities is poorly understood, particularly with respect to life stages before and after bloom events and how the benthic and pelagic communities are coupled.

- The fate and transport of benthic-associated cyanotoxins, including photo- and biodegradation, bioaccumulation, biotransformation, and sorption, are understudied and should be investigated with respect to proximate and downstream communities.

- Novel monitoring techniques may need to be developed if techniques for monitoring planktonic populations and pelagic toxins cannot accommodate the complexity of the benthic substrates.

- A strong foundational understanding of the ecology of benthic cyanobacteria will facilitate improved monitoring and forecasting of benthic cyanoHAB events.

- A renewed emphasis on basic research and population monitoring must be undertaken for benthic cyanobacteria and cyanotoxins. Further technical work is necessary to fill crucial information gaps and encourage innovative approaches to address these complex communities.

- A framework for which tools and techniques to use and when must be developed and employed by researchers so that sampling is standardized where findings can contribute to the general understanding of these communities.

- The efficacy of remote sensing, various field sampling techniques, and omics techniques for cyanobacteria and cyanotoxin research and monitoring must be assessed.

- Cost-effective tools that can quickly screen for cyanotoxins in or near benthic mats should be developed. 
- The direct management of benthic cyanobacteria communities is poorly developed but may become a priority once the basic ecology and adverse effects of the community are better understood.

- Research efforts should be collaborative in nature, using technical strengths and unique capabilities from various groups. This process will maximize and accelerate work and begin to fill critical information gaps.

- Collaborative stakeholders should include federal, state, and local agencies; academia; water resource managers; practitioners; industry; and nonprofit organizations.

- A nexus for information on benthic cyanobacteria and their toxins should be established to minimize duplication of research efforts and to stimulate new collaborations.

- Adequate annual funding levels will be required for research and devlopment efforts and for responding to benthic cyanoHAB events. 


\section{Bibliography}

Backer, L.C. (2012). Freshwater algal blooms and public health. Lake Line, 32(3): 7-9.

Backer, L.C., McNeel, S.V., Barber, T., Kirkpatrick, B., Williams, C., Irvin, M., Zhou, T., Johnson, T.B., Nierenberg, K., Aubel, M., PePrell, R., Chapman, A., Foss, A., Corum, S., Hill, V. R., Kieszak, S. M., and Cheng, Y. S. (2010). Recreational exposure to microcystins during algal blooms in two California lakes. Toxicon, 55(5): 909-921.

Bishop, W., Johnson, B. M., and Rodgers, J. (2019). Microcystin concentrations following treatments of harmful algal blooms. Handout. Accessed 11/18/2019 at https://www.aquaticcontrol.com /wp- content/uploads/2017/o1/Microcystinconcentrations-follow ing-treatments-of-harmful-algal-blooms_.pdf.

Bouma-Gregson, K., Kudela, R. M., and Power, M. E. (2018). Widespread anatoxin-a detection in benthic cyanobacterial mats throughout a river network. PLoS ONE, 13(5): e0197669.

Bouma-Gregson, K., Power, M. E., and Bormans, M. (2017). Rise and fall of toxic benthic freshwater cyanobacteria (Anabaena spp.) in the Eel river: Bouyancy and dispersal. Harmful Algae 66: 79-87.

Carbis, C.R., Rawlin, G.T., Grant, P., Mitchell, G.F., Anderson, J.W. and McCauley, I. (1997). A study of feral carp Cyprinus carpio L., exposed to Microcystis aeruginosa at Lake Mokoan, Australia, and possible implication on fish health. Journal of Fish Diseases, 20: 81-91.

D’Agostino, P. M. D., Song, X., Neilan, B. A., and Moffitt, M. C., (2016). Proteogenomics of a saxitoxin-producing and non-toxic strain of Anabaena circinalis (cyanobacteria) in response to extracellular $\mathrm{NaCl}$ and phosphate depletion. Environmental Microbiology, 18(2): 461-476.

DeMott, W.R., Zhang, Q., and Carmichael, W.W. (1991). Effects of toxic cyanobacteria and purified toxins on the survival and feeding of a copepod and three species of Daphnia. Limnology and Oceanography, 36(7): 1346-1357.

Dick, G. J., and Lam, P. (2015). Omic approaches to microbial geochemistry. Elements, 11(6): 403-408.

Ferrao-Filho, A. S. D., and Kozlowsky-Suzuki, B. (2011). Cyanotoxins: Bioaccumulation and effects on aquatic animals. Marine Drugs, 9(12): 2792-2772.

Fletcher, A. E., Howard, M. D. A., Stancheva, R., Kudela, R. M., Stein, E. D., Sutula, M. A., Busse, L. B., and Sheath, R. G. (2015). Wadeable streams as widespread sources of benthic cyanotoxins. Harmful Algae, 49: 205-116.

Ford, A. K., Bejarano, S., Nugues, M. M., Visser, P. M., Albert, S., and Ferse, S. C. A. (2018). Reefs under siege - the rise, putative drivers, and consequences of benthic cyanobacterial mats. Frontiers in Marine Science, 5(18): 1-15. 
Hense, I., and Beckmann, A. (2006). Towards a model of cyanobacteria life cycle - effects of growing and resting stages on bloom formation of $\mathrm{N}_{2}$-fixing species. Ecological Modelling, 195: 205-218.

Kuiper-Goodman, T., Falconer, I., and Fitzgerald, J. (1999). Human health aspects of cyanotoxins, in Toxic Cyanobacteria in Water: A Guide to their Public Health Consequences, Monitoring, and Management, Chorus, I., and Bartram, J (Eds.). WHO.

Loftin, K. A., Clark, J. M., Journey, C. A., Kolpin, D. W., Van Metre, P. C., Carlisle, D., and Bradley, P. M. (2016a). Spatial and temporal variation in microcystin occurrence in wadeable streams in the southeast United States. Environmental Toxicology and Chemistry, 35(9): 2281-2287.

Loftin, K. A., Graham, J. L., Hilborn, E. D., Lehmann, S. C., Meyer, M. T., Dietze, J. E., and Griffith, C. B. (2016b). Cyanotoxins in inland lakes of the United States: Occurance and potential recreational health risks in the EPA National Lakes Assessment 2007. Harmful Algae, 56: 77-90.

McAllister, T. G., Wood, S. A., and Hawes, I. (2016). The rise of toxic benthic Phormidium proliferations: A review of their taxonomy, distribution, toxin content and factors regulating prevalence and increased severity. Harmful Algae, 55: 282-294.

Miller, M. A., Kudela, R. M., Mekebri, A., Crane, D., Oates, S. C., Tinker, M. T., Staedler, M., Miller, W. A., Toy-Choutka, S., Dominik, C., Hardin, D., Langlois, G., urrary, M., Ward, K., and Jessup, D. A. (2010). Evidence for a novel marine harmful algal bloom: cyanotoxin (microcystin) transfer from land to sea otters. PLoS ONE, 5(9): e12576.

Newcombe, G., House, J., Ho, L., Baker, P., and Burch, M. (2010). Management strategies for cyanobacteria (blue-green algae): A guide for water utilities. Research Report No 74, Water Quality Research Australia Limited, Adelaide.

Nienaber, M. A., and Steinitz-Kannan, M. (2018). A Guide to Cyanobacteria: Identification and Impact. University Press of Kentucky, Lexington, KY.

NOAA (2019). Harmful Algal Blooms: Tiny organsims with a toxic punch. National Oceanic and Atmospheric Administration, accessed November 15, 2019 at https://oceanservice.noaa.gov/hazards/hab/.

ORSANCO (2019). Algae and nutrient monitoring. Ohio River Valley Water Sanitation Commission, accessed November 15, 2019 at http://www.orsanco.org/programs/algae-nutrient-monitoring/.

Paerl, H. W. (1988). Nuisance phytoplankton blooms in coastal, estuarine, and inland waters. Limnology and Oceanography, 33(4, part 2): 823-847.

Princiotti, S. D., Hendricks, S. P., and White, D.S. (2019). Production of cyanotoxins by Microcystis aeruginosa mediates interactions with the mixotrophic flagellate Cryptomonas. Toxins, 11: 223. 
Puddick, J., Prinsep, M. R., Wood, S. A., Kaufononga, S. A. F., Cary. S. C., and Hamilton, D. P. (2014). High levels of structural diversity observed in microcystins from Microcystis CAWBG11 and characterization of six new microcystin congeners. Marine Drugs, 12: 5372-5395.

Quiblier, C., Wood, S., Echinque-Subiabre, I., Heath, M., Villeneuve, A., and Humbert, J.F. (2013). A review of current knowledge on toxic benthic freshwater cyanobacteria - Ecology, toxin production and risk management. Water Research, 47: 5464-5479.

Rowe, M. D., Anderson, E. J., Wynne, T. T., Stumpf, R. P., Fanslow, D. L., Kijanka, K., Vanderploeg, H. A., Strickler, J. R., and Davi, T. W. (2016). Vertical distribution of buoyant Microcystis blooms in a Lagrangian particle tracking model for shortterm forecast in Lake Erie. Journal of Geophysical Research: Oceans, 121 (7): 5296-5314.

Sivonen, K., and Jones, G. (1999). Cyanobacterial toxins, in Toxic Cyanobacteria in Water: A Guide to their Public Health Consequences, Monitoring, and Management, Chorus, I., and Bartram, J (Eds.). WHO.

Stumpf, R. P., Davis, T. W., Wynne, T. T., Graham, J. L., Loftin, K. A., Johengen, T. H., Gossiaux, D., Palladino, D., and Burtner, A. (2016). Challenge for mapping cyanotoxins patterns from remote sensing of cyanobacteria. Harmful Algae, 54: $160-173$.

Touchette, B. W., Edwards, C.T., and Alexander, J. (2008). A comparison of cyanotoxin release following bloom treatments with copper sulfate or sodium carbonate peroxyhydrate, in Cyanobacterial Harmful Algal Blooms: State of the Science and Research Needs, H. K. Hudnell (Ed.). P. 314-315. Springer, New York.

USEPA. (2017) Guidelines and Recommendations. U. S. Environmental Protection Agency, Accessed November 22, 2019 at https://19january2017snapshot.epa.gov/nutrient-policy-data/guidelines-andrecommendations_.html.

USEPA. (2019). Cyanobacterial Harmful Algal Blooms (CyanoHABs) in water bodies. U.S. Environmental Protection Agency, accessed November 15, 2019 at https://www.epa.gov/cyanohabs.

USGS. (n.d.) Algal and other Environmental Toxins Laboratory - Lawrence, Kansas. U.S. Geological Survey, accessed December 20, 2019 at https://www.usgs.gov/mission-areas/environmental-health/science/algal-andother-environmental-toxins-laboratory-lawrence?qtscience_center_objects=o\#qt-science_center_objects.

Wood, S. A. Kelly, L. T., Bouma-Gregson, K., Humbert, J.-F., Laughinghouse, H. D., Lazorchack, J., McAllister, T. G., McQueen, A., Pokrzywinski, K., Puddick, J., Quiblier, C., Reitz, L. A., Ryan, K. G., Vadeboncoeur, Y., Zastepa, A., and Davic, T. W. (2020). Toxic benthic freshwater cyanobacterial proliferations: Challenges aand solutions for enhancing knowledge and improving monitoring and mitigation. Freshwater Biology, 65(10): 1824-1842. 
Wynne, T.T., Stumpf, R.P., Tomlinson, M.C., and Dyble, J. (2010). Characterizing a cyanobacterial in western Lake Erie using satellite imagery and meteorologic data. Limnology and Oceanography, 55 (5): 2025-2036.

Zastepa, A., Pick, F. R., and Blais, J. M. (2017a). Distribution and flux of microcystin congeners in lake sediments. Lake and Reservoir Management, 33(4): 444-451.

Zastepa, A., Pick, F. R., Blais, J. M., and Saleem, A. (2015). Analysis of intracellular and extracellular microcystin variants in sediments and pore waters by accelerated solvent extraction and high performance liquid chromatography-tandem mass spectrometry. Analytica Chimica Acta, 872: 26-34.

Zastepa, A., Taranu, Z. E., Kimpe, L. E., Blais, J. M., Gregory-Eaves, I., Zurawell, R. W., and Pick, F. R. (2017b). Reconstructing a long-term record of microcystins from the analysis of lake sediments. Science of the Total Environment, 579: 893-901. 


\section{Appendix A: Workshop Agenda}

CyanoSED: A Workshop on Benthic Cyanobacteria and Cyanotoxins

Workshop Objectives:

1. Understand current research in benthic/sediment-associated HABs related to benthic mat-forming (including attached, periphytic and filamentous) cyanobacteria and benthic-pelagic (planktonic) coupling of bloom events.

2. Identify knowledge gaps and topic areas worth pursing in more detail.

3. Facilitate engagement among federal, local and state government agencies; academic institutions; and industry partners to continue coordination and collaboration on sediment/benthic-associated HABs issues.

4. Effectively disseminate workshop results by facilitating publication of research priorities and detailed key discussions developed through this workshop.

\section{August 6th, 2018 Morning Session}

o80o - Arrive and check-in

o815 - Welcome and Opening Remarks - Jim Lazorchak, US EPA

o830 - General Overview and Objectives - Kaytee Pokrzywinski, USACE ERDC

0900 - 1000 - Invited Presentations

Ecology of Periphytic and Planktonic Cyanobacteria

Session Chair: Susie Wood, Cawthron Institute (NZ)

0900 - Susie Wood, Cawthron Institute (NZ)

0920 - Keith Bouma-Gregson, UC Berkeley

0940 - Miriam Kannan, NKU

1000-1010 - Break - Sponsored by Lonza

1010-1140 - Breakout Session

Periphytic and planktonic cyanobacteria ecology in lakes and rivers

1140-1210 - Breakout Session Summary 
1210-1300 - Working Lunch

1220-1240 - Richard Harrison, ORSANCO

Ohio River HABs Work Group Overview

1240-1300 - Jade Young, USACE LRL

Benthic HAB Work Group Overview

\section{Afternoon Session}

1300-1420 - Invited Presentations

Monitoring Cyanobacteria and Cyanotoxins

Session Chair - Heather Raymond OH EPA

1300 - Heather Raymond, OH EPA

1320 - Alan Lindquist and Jingrang Lu, US EPA

1340 - Tim Davis, BGSU

1400-1420 - Break - Sponsored by Lonza

1420-1620 - Breakout Session

Tracking and monitoring cyanobacteria and their associated toxins

1620-1650 - Breakout Session Summary

1650-1700 - Closing Remarks and Adjourn

\section{August 7th, 2018}

\section{Morning Session}

o80o - Welcome and Opening Remarks - Tim Davis, BGSU

o810-0830 - A national perspective on HABs and the USACE - Erich Emery, USACE LRD

o830-0930 - Invited Presentations

Identification and Toxicity of Cyanotoxins in Complex Matrices

Session Chair - Jonathan Puddick, Cawthron Institute (NZ)

o830 - Jonathan Puddick, Cawthron Institute (NZ)

o850 - Meredith Howard, SCCWRP

0910 - Arthur Zastepa, Environment and Climate Change Canada

0930-0940 - Break - Sponsored by AERF

0940-1140 - Breakout Session 
Methods for detecting benthic/sediment bound cyanotoxins and current research gaps

1130-1200 - Breakout Session Summary

1200-1250 - Working Lunch

1220-1250 - Erin Stelzer, USGS

Omics approaches to cyanobacteria/toxin detection

\section{Afternoon Session}

1250-1400 - Invited Presentations

Fate and Transport of Cyanobacteria and Cyanotoxins

Session Chair - Andrew McQueen, USACE ERDC

1250 - Kaytee Pokrzywinski, USACE ERDC

1310 - Mark Rowe, GLERL

1330 - Andrew McQueen, USACE ERDC

1350 - Keith Loftin, KS USGS

$1410-1420$ - Break - Sponsored by AERF

$1420-1600$ - Breakout Session

Assessing the fate and transport of benthic cyanobacteria/toxins and their associated environmental and human health risks

1600 - 1630 - Breakout Session Summary

$1630-1650$ - Publication discussion and writing assignments 1650 - 1700 - Closing Remarks and Adjourn

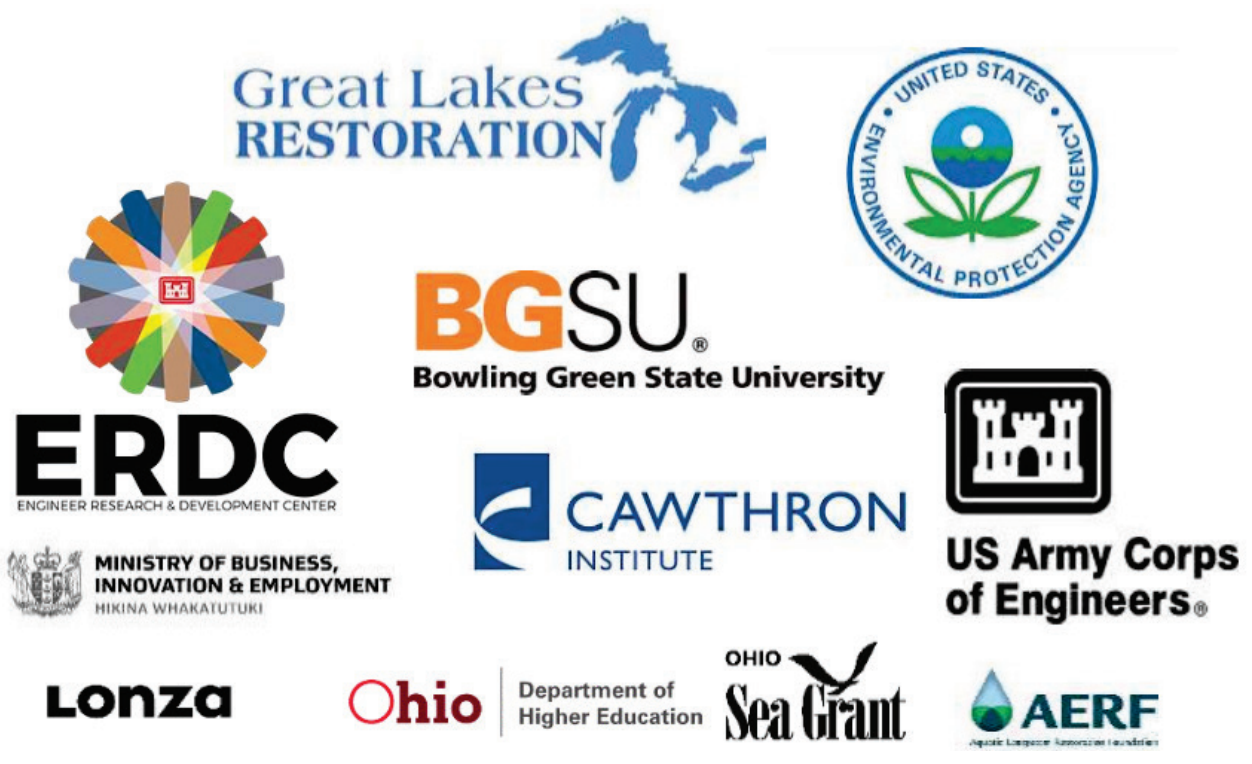




\section{Appendix B: Workshop Participants}

Government Agencies

Brandon Boyd, ERDC

Tony Friona, ERDC

Karl Indest, ERDC

Jeff King, ERDC

Andrew McQueen, ERDC

Lee Moores, ERDC

Linda Nelson, ERDC

Kaytee Pokrzywinski, ERDC

Brooke Steevens, ERDC

Burton Suedel, ERDC

Christine VanZomeren, ERDC

Karen Keil, USACE-Buffalo District

Erich Emery, USACE-Great Lakes and Ohio River Division

Thaddaeus Tuggle, USACE-Huntington District

Jeremy Crossland, USACE Headquarters

Jade Young, USACE-Louisville District

Ashely Fuentes, USACE-Nashville District

Mark Bagley, USEPA

Christina Bennett-Stamper, USEPA

Jackie Fischer, USEPA

Terri Jicha, USEPA

Rochelle Lablosa, USEPA

Jim Lazorchak, USEPA

Jingrang Lu, USEPA

Darren Lytle, USEPA

Heath Mash, USEPA

Christopher Nietch, USEPA

Jacques Oliver, USEPA

Jorge Santodomingo, USEPA

Robert Zucker, USEPA

Keith Loftin, USGS

Barry Rosen, USGS

Erin Stelzer, USGS

Quay Dortch, NOAA-National Centers for Coastal Ocean Science (NCCOS)

John Ramsdell, NOAA-NCCOS

Marc Suddleson, NOAA-NCCOS

John Wickham, NOAA-NCCOS 
Brian Astifan, NOAA National Weather Service (NWS)-Ohio River Forecast Center Abram SaSilva, NOAA NWS-Ohio River Forecast Center Jim Noel, NOAA NWS-Ohio River Forecast Center Mark Rowe, NOAA-Great Lakes Environmental Research Laboratory Patricia Klonicki, City of Cincinnati Lisa Bernard, North Coast Regional Water Quality Control Board Arthur Zastepa, Environment and Climate Change Canada Colin Arnold, Kentucky Energy and Environment Cabinet Robert Blair, Kentucky Energy and Environment Cabinet Steve Bieber, Metropolitan Washington Council of Governments Margaret Spoo-Chupka, Metropolitan Water District of Southern California Ruther Briland, Ohio EPA Heather Raymond, Ohio EPA Casy Lyon, Oregon Health Authority Richard Harrison, Ohio River Valley Water Sanitation Commission Heather Mayfield, Ohio River Valley Water Sanitation Commission Harry Stone, Ohio River Valley Water Sanitation Commission Brandon Keplinger, West Virginia Department of Natural Resources

Academia

Timothy Davis, BGSU

Robert Michael McKay, BGSU

Kevin Sellner, Hood College

Erika Haug, North Carolina State University

Joshua Cooper, Northern Kentucky University

Miriam Steinitz Kannan, Northern Kentucky University

Michael Miller, University of Cincinnati

Keith Bouma-Gregson, University of California-Berkeley

Raphael Kudela, University of California-Santa Cruz

David Berthold, University of Florida

Dail Laughinghouse, University of Florida

Thomas Bridgeman, University of Toledo

Yvonne Vadeboncoeur, Wright State University

Nonprofit Organizations

Carlton Layne, Aquatic Ecosystem Restoration Foundation Meredith Howard, Southern California Corporate Wetlands Restoration Partnership 
Industry

Laura Kelly, Cawthron Institute

Robert Matheson, Cawthron Institute

Jonathan Puddick, Cawthron Institute

Susie Wood, Cawthron Institute

Bill Ratajczyk, Lonza Group

Greg Ford, Phytoxigene 


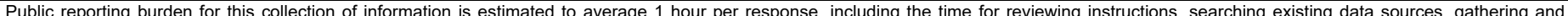

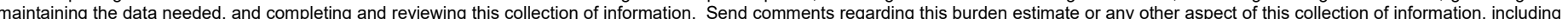

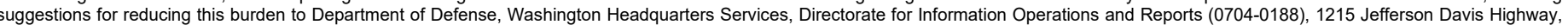

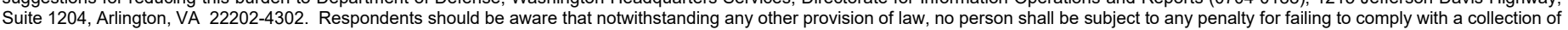
information if it does not display a currently valid OMB control number. PLEASE DO NOT RETURN YOUR FORM TO THE ABOVE ADDRESS.

\begin{tabular}{|l|l|l}
\hline 1. REPORT DATE (DD-MM-YYYY) & 2. REPORT TYPE & 3. DATES COVERED (From - To)
\end{tabular} August 2021 Special Report

\section{TITLE AND SUBTITLE}

Aligning Research and Monitoring Priorities for Benthic Cyanobacteria and Cyanotoxins: A Workshop Summary

5a. CONTRACT NUMBER

5b. GRANT NUMBER

5c. PROGRAM ELEMENT NUMBER

5d. PROJECT NUMBER

\section{AUTHOR(S)}

Kaytee Pokrzywinski, Kaitlin Volk, Taylor Rycroft, Susie Wood, Tim Davis, and Jim Lazorchak

\section{PERFORMING ORGANIZATION NAME(S) AND ADDRESS(ES)}

See next page.

\section{SPONSORING / MONITORING AGENCY NAME(S) AND ADDRESS(ES)}

USACE Buffalo District and Great Lakes Restoration Initiative 1776 Niagara Street

Buffalo, NY 14207-3106

\section{DISTRIBUTION / AVAILABILITY STATEMENT}

Approved for public release; distribution is unlimited.

\section{SUPPLEMENTARY NOTES}

Funded by MIPR W81EU680856786.

\section{ABSTRACT}

In 2018, the US Army Engineer Research and Development Center partnered with the US Army Corps of Engineers-Buffalo District, the US Environmental Protection Agency, Bowling Green State University, and the Cawthron Institute to host a workshop focused on benthic and sediment-associated cyanobacteria and cyanotoxins, particularly in the context of harmful algal blooms (HAB). Technical sessions on the ecology of benthic cyanobacteria in lakes and rivers; monitoring of cyanobacteria and cyanotoxins; detection of benthic and sediment-bound cyanotoxins; and the fate, transport, and health risks of cyanobacteria and their associated toxins were presented. Research summaries included the buoyancy and dispersal of benthic freshwater cyanobacteria mats, the fate and quantification of cyanotoxins in lake sediments, and spatial and temporal variation of toxins in streams. In addition, summaries of remote sensing methods, omic techniques, and field sampling techniques were presented. Critical research gaps identified from this workshop include (1) ecology of benthic cyanobacteria, (2) identity, fate, transport, and risk of cyanotoxins produced by benthic cyanobacteria, (3) standardized sampling and analysis protocols, and (4) increased technical cooperation between government, academia, industry, nonprofit organizations, and other stakeholders. Conclusions from this workshop can inform monitoring and management efforts for benthic cyanobacteria and their associated toxins.

\section{SUBJECT TERMS}
Benthos
Contaminated sediments
Cyanobacteria
Cyanobacterial toxins
Algal blooms

\section{SECURITY CLASSIFICATION OF:}

\section{a. REPORT}

Unclassified

\section{b. ABSTRACT}

Unclassified

\section{c. THIS PAGE}

Unclassified
17. LIMITATION OF ABSTRACT

SAR
18. NUMBER OF PAGES

41 19a. NAME OF RESPONSIBLE PERSON 19b. TELEPHONE NUMBER (include area code) 
Environmental Laboratory

US Army Engineer Research and Development Center 3909 Halls Ferry Road

Vicksburg, MS 39180-6133

Credere Associates, LLC.

776 Main Street

Westbrook, Maine 04092

Cawthron Institute

98 Halifax Street East

Nelson 7010, New Zealand

Department of Biological Sciences

Bowling Green State University

Bowling Green, Ohio 43403

National Exposure Research Laboratory

US Environmental Protection Agency Office of Research and Development

Cincinnati, Ohio, USA 